University of Wollongong

Research Online

Faculty of Social Sciences - Papers (Archive) Faculty of Arts, Social Sciences \& Humanities

2008

Contrapuntal geographies: the politics of organizing across sociospatial difference

Noel Castree

University of Wollongong, ncastree@uow.edu.au

David Featherstone

University of Liverpool

Andrew Herod

University Of Georgia

Follow this and additional works at: https://ro.uow.edu.au/sspapers

Part of the Education Commons, and the Social and Behavioral Sciences Commons

Research Online is the open access institutional repository for the University of Wollongong. For further information contact the UOW Library: research-pubs@uow.edu.au 


\title{
Contrapuntal geographies: the politics of organizing across sociospatial difference
}

\begin{abstract}
This chapter is written against the background of two closely interlinked developments. The first is the increase in the number and type (or at least visibility) of transborder political movements this last decade or so, particularly during the years of what David Slater (2003: 84) calls 'the post-Seattle conjuncture'. The second is a sharp increase in geographical writing on these multifarious attempts to bridge sociospatial difference in order to challenge neo-liberal versions of 'globalization'. To oversimplify matters, we can say that this literature relates to two groups of space-spanning social actors: those associated with the labour movement (broadly conceived) and those who are part of the New Left social (and environmental) movements that emerged in the 1980s and 1990s.
\end{abstract}

\section{Keywords}

era2015, difference, politics, contrapuntal, organizing, geographies, across, sociospatial

\section{Disciplines}

Education | Social and Behavioral Sciences

\section{Publication Details}

Castree, N., Featherstone, D. \& Herod, A. (2008). Contrapuntal geographies: the politics of organizing across sociospatial difference. In K. Cox, M. Low \& J. Robinson (Eds.), The SAGE Handbook of Political Geography (pp. 305-321). London: SAGE Publications Ltd. http://www.uk.sagepub.com/ booksProdDesc.nav?prodld=Book225561\#tabview=toc 


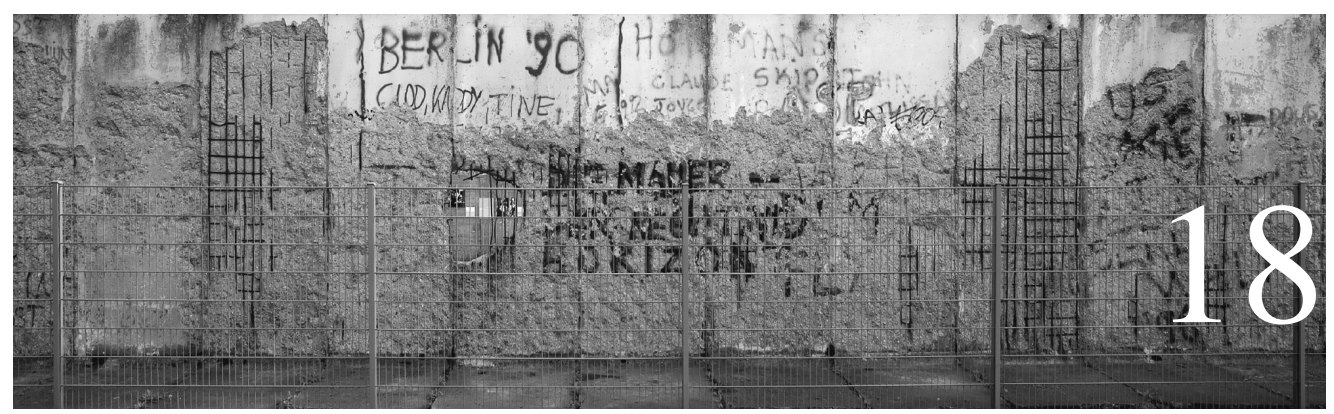

\title{
Contrapuntal Geographies: The Politics of Organizing Across Sociospatial Difference
}

\author{
Noel Castree, David Featherstone and \\ Andrew Herod
}

Difference is as much about geography ... as it is about 'race', class, gender, ethnicity and the like.

David Harvey (1998: 727)

As geographers are prone to emphasize, differing groups of people in differing sociospatial locations around the world have distinct, placerelated interests and identities, so that notions of global [solidarity] ... will at best display a vision and at worst betray an illusion.

Jim Glassman (2003: 514)

\section{INTRODUCTION}

This chapter is written against the background of two closely interlinked developments. The first is the increase in the number and type (or at least visibility) of transborder political movements this last decade or so, particularly during the years of what David Slater (2003: 84) calls 'the post-Seattle conjuncture'. The second is a sharp increase in geographical writing on these multifarious attempts to bridge sociospatial difference in order to challenge neo-liberal versions of 'globalization'. To oversimplify matters, we can say that this literature relates to two groups of space-spanning social actors: those associated with the labour movement (broadly conceived) and those who are part of the New Left social (and environmental) movements that emerged in the 1980s and 1990s.

A central aspect of many projects seeking to understand alternatives to neo-liberal globalization is an exploration of how acts of international solidarity have dealt with the ineradicable fact of geographical difference. 'Difference', of course, has been 'on the agenda' of the social sciences and humanities for well over a decade, but often in highly ageographical or only metaphorically spatial ways (Smith and Katz, 1993). Thus, although many geographers have argued that difference is necessarily spatial and that this fact affects the content and form of politics, it is far from self-evident what exactly 'geographical difference' is and there is more than one way to understand how, why and with what effects it may be 'crossed'. As if this didn't complicate matters enough, there is no disciplinary consensus on how best to conceptualize any such 'crossing of difference'. Broadly speaking, two alternatives have presented themselves. On the one side, a great many human geographers have found the language of geographical scale to be a key resource for studying the politics of sociospatial difference in the New Labour Internationalism (NLI) and Transnational Social Movements (TSMs). Here, 'scale politics' is comprehended through such (now) familiar ideas as 'up-scaling', 'down-scaling' and, more recently, 'scale-bending'. On the other side, this scalar 
language has recently been challenged by those enamoured with the idea of sociospatial networks. Interestingly (and perhaps significantly), whilst it would certainly be overly simplistic to suggest that much of the NLI research has used a scalar framework whilst the newer work on TSMs has favoured network thinking, there is nonetheless more than a grain of truth to this claim. Heuristically, then, we are dealing here with what have been called 'topographical' and 'topological' ways of thinking, respectively (Marston et al., 2006; see also Amin, 2002, 2004).

In seeking to understand how various social actors have sought to engage with geographical difference, we outline how these two ways of spatial thinking have shaped contemporary political geography. Our discussion proceeds as follows. In the next section we review some of the key theoretical contributions on geographical difference that have underpinned the more empirical research discussed later in the chapter. Since much of that research has, as we shall see, accented the importance of place, the theoretical contributions discussed relate to this way of characterizing geographical difference (rather than to, say, 'region' or 'nation', even though these two terms are sometimes used by human geographers interchangeably with the term 'place'). Specifically, we examine the ideas of Kevin Cox, David Harvey and Doreen Massey on why place and locality matter a great deal to the content and form of political projects. The differences between Cox and Harvey, on the one side, and Massey, on the other, are as instructive as are the similarities. Thus, Cox and Harvey have been read as offering a view of inter-place politics that suggests geographical scale is the most productive way to grasp how, why and with what results spatial difference may be crossed. Massey's ideas, by contrast, have been appropriated by those researchers favouring the less 'territorial' language of networks. Yet these differences aside, all three authors insist on something that has permeated the research on the NLI and TSMs; namely, that we adopt a relational perspective on place difference and thus on geographical politics. For several reasons, as we shall see, this is thought to be a preferable way of conceiving of geographical difference compared to others currently abroad in academe or the wider society. Following from this, in the third and fourth sections we review theoretically informed but empirically grounded studies of the NLI and TSMs. The third section summarizes the increasingly complex disciplinary debates on geographical scale and links these to empirical studies of labour activism across space. The fourth section, which discusses recent geographical research into TSMs, explores the differences (by no means obvious) between network and scalar ways of analysing the politics of inter-place solidarity. Are these differences significant and, if so, why?
Does network analysis betoken a new way of thinking about spatial politics? If so, is Colin Flint (2003: 628) - who has insisted that current geographical research on transborder solidarity 'offers knowledge that is essential to political actors, especially the marginalized' - right to think that labour and TSM activists can usefully learn from academic studies of their geographical organizing?

What emerges from our review, as readers will discover, is that whilst there is no consensus on the raft of issues we consider, research into the politics of translocal organizing by unions and TSMs nonetheless has a fuzzy coherence. It is a coherence captured in our chapter title, 'contrapuntal geographies'. As the musically inclined among our readers will know, counterpoint is the art of harmonizing different melodies. In the present context, we use the term to refer to efforts to conjoin local place-based actors with distant others in order to serve common interests yet without sacrificing local commitments and aspirations - that is to say, to describe how social actors seek to maintain their local uniqueness within any broader effort to develop anti-neo-liberal commonalities across global space.

\section{GEOGRAPHICAL DIFFERENCE, GEOGRAPHICAL DISTANCE AND POLITICS}

Jean Gottman (1951) memorably observed that there would be no need for a discipline called 'geography' if the world were a smooth sphere. As we noted above, a resurgent interest in place and locality is one of the principal ways that human geographers have registered their continuing preoccupation with geographical difference $-\mathrm{a}$ preoccupation briefly thwarted during geography's 'nomothetic turn' in the 1950s and 1960s. In relation to politics, John Agnew's (1987) formative book Place and Politics was an early explication of why place matters to the formation and enactment of political projects - be they state-led, workerled or a product of civil society groups. Agnew identified three dimensions of place, each of which specifies a particular locality's relative difference from others near and far. These were place as location (a distinct point on the Earth's surface), as locale (a physical arena for everyday life) and as a locus of identity (a focus for personal and collective loyalty, affect and commitment).

Some years after Place and Politics was published, a flurry of contributions appeared on why place-based actors who are formally outside the state apparatus often need to reach out across space in their efforts to defend or enhance local interests. Much of this early work did not thematize place in terms of 'difference' (except implicitly), but it 
did initiate what is now a well-developed understanding of how scale (including the 'local' scale, which we tend to synonymize with 'place') is both a resource and constraint in place-based struggles (see Jonas, 1994; Miller, 1994; Staeheli, 1994). As such (and as we shall see in the next section), it took forward the suggestive ideas of Neil Smith (1984) and Peter Taylor $(1981,1982)$ on the 'politics of scale'. A decade on, scalar understandings of geographical politics are being challenged by network forms of analysis (presaged in Murdoch and Marsden's [1995] essay on 'actor-spaces'; see also Routledge, 1993) in which place difference and the contrapuntal politics of interlocal organizing is a core preoccupation. However, as we mentioned in the introduction, what both scalar and network analyses of geographical politics have in common is a commitment to understanding place in relational terms.

Though by no means the only relational theorists of place in human geography, Cox, Harvey and Massey have been uncommonly influential in this area. Whilst we are not suggesting that all the researchers whose work is discussed in the next two sections have formally appropriated Cox's, Harvey's or Massey's thinking, this thinking has been difficult to ignore for three reasons. First, it offers prima facie reasons why, in Sophie Watson's (2004: 209) words, geographical difference 'is here to stay'. Second, it deals with the two main dimensions of place covered in Agnew's tripartite definition; that is, the 'objective' dimension (places as distinct locations and locales) and the 'subjective' dimension (places as the sites and subjects of identity, belonging and affect). Finally, Cox, Harvey and Massey all give a strong steer in their writing to which kinds of geographical difference - at the level of both thought and practice are 'good' and which are 'bad'. Given that 'critical geographers' have undertaken the lion's share of empirical research into translocal solidarity in geography, the highly normative cast of Cox's, Harvey's and Massey's argument has helped to orientate the kinds of judgements these geographers make about the geographical politics analysed in their case studies.

\section{Cox: Spaces of Dependence and Engagement}

In his work on urban politics, Kevin Cox (1998) has made an instructive distinction between 'spaces of dependence' and 'spaces of engagement'. Building on earlier work into growth coalitions and crossclass alliances in Western cities (e.g. Cox and Mair, 1988), he has offered a plenary account of why locally based actors (e.g. particular workforces or small firms) necessarily have a stake in the nature and future of their locality. Taking these actors' perspective, he argues that whilst their political activity is fundamentally about place, it routinely extends beyond place into a geographically wider sphere of influence and action.

The theoretical basis of Cox's argument is Harvey's germinal account of the geography of capital accumulation (Harvey, 1982, chap. 13; 1985a). For Cox (1998: 2), the spatio-temporal tension between fixity and motion that is endemic to capitalism explains why many locally based actors focus their political energies on what he calls their 'space of dependence' (those more-or-less localized social relations [and institutions] upon which we depend for the realization of essential interests and for which there are no substitutes elsewhere [and which] define place-specific conditions for our material well-being and our sense of significance). In Agnew's terms, these spaces are not simply the locations in which certain actors happen to be but, rather, the locales upon which they depend for their daily survival. Yet Cox also argues that locally based actors must necessarily have an eye to their 'space of engagement' ('the space in which the politics of securing a space of dependence unfolds [and which] may be at a more global scale than the space of dependence' [ibid.]). For Cox, such a dependence on particular locales feeds into place identity (the third of Agnew's place-dimensions) not simply because people are socialized in specific places but also because the material character of those places decisively shapes people's economic and other interests. As Cox (ibid.: 5) puts it, '[Certain] agents have [specifically] local interests. These are interests in appropriating/realizing profits, rents, wages [or] taxes in particular places. Changing economic geographies at more global scales [can] threaten the realization of these local interests'. Hence, locally dependent actors clearly have a stake in controlling, or at the least influencing, other actors whose actions can decisively affect the fate of their locality. Though some of the latter will be found in the same location as they live, many will be national trade unions, transnational firms, (supra)national state bodies or international civil society organizations. Harnessing these non-local actors to local advantage can help place-dependent groups address the problem of "ensuring that [economic] value ... continues to flow through their [locality]' (ibid.: 5). Clearly, then, whether they act alone or in alliance, these place-dependent groups will have very different spaces of engagement depending on the place in question. Likewise, the precise forms of 'political action' across space will vary too, depending on the non-local actors who are being influenced or enrolled.

Although we have simplified what, in truth, is a rather dense argument, Cox's normative stance on the politics of geographical difference is subtle. Certainly, it respects the tension between 
fixity and motion that underpins the nature of capitalism. Thus, on the one side, he is critical of understandings that reify or hypostatize place, for such understandings (which Merrifield [1993] calls 'Cartesian') presume both that places have 'internal' characteristics that are readily distinguishable from 'external' ones, and that places are things (infrastructures and peoples) that are ontologically distinct from the relations and processes that link them with other places. Hence, Cox argues that it is no surprise that Cartesian conceptions of place die hard, since it is precisely the necessary physical fixity of portions of capitalism that create the appearance of diverse locations and locales set against a more abstract realm of 'space' or 'the global' (see also Cox, 2005).

On the other side, though, Cox is neither dismissive of political projects that aim to engender certain forms of local difference, nor does he envisage the ultimate eclipse of geographical differentiation by political or any other means. Thus, his 1997 edited book Spaces of Globalization (subtitled 'Reasserting the power of the local') was a critique of the 'globaloney' that equates heightened inter-place connectivity with placelessness and homogeneity. This critique was normative as much as cognitive, arising not simply from the abundant evidence that place difference is here to stay (because capitalism thrives on the creation of geographical differentiation, not its elimination), but also from Cox's conviction that relatively disadvantaged place-based actors (e.g. the unemployed or already straitened workforces) have much to gain by creating a space of dependence that works in their favour in the medium and long term. The difficulty in this, however, is that the rules of the capitalist game often mean that these actors' space of engagement is harnessed in ways that encourage 'beggar-thy-neighbour' tactics, a kind of geographical practice in the face of difference that is always about 'winners' and 'losers'. For his part, though, Cox would prefer forms of interplace alliance that do not play locally dependent groups against one another but which instead, in Massey's (1993) terms, would encourage a 'progressive sense of place' that would lead locally marginal or vulnerable groups to engage cooperatively with distant others - that is, promote an engagement that is undertaken in recognition of the fact that creating 'desirable' sociospatial differences for all depends upon agreeing to common goals and joined-up strategies.

\section{David Harvey: Militant Particularism and Global Ambition}

We have already mentioned in passing Harvey's early-to-mid-1980s thinking about the inconstant geography of capitalism. Detailing his argument in
The Limits to Capital, The Urbanization of Capital and other publications, Harvey maintains that geographical difference is actively wrought out of the interconnectivity in a capitalist universe, making it internal (though not reducible) to this mode of production. From a 'capital-logic' perspective, then, uneven geographical development is not only necessary but functional since, among other things, it fragments working-class opposition to exploitation, creative destruction, unemployment and the like. From the perspective of 'people on the ground', though, Harvey's 1980s works recognized that oppressed groups have material and emotional investments in place that cannot be dismissed as mere ideological constructs (see the essays in Consciousness and the Urban Experience [1985b], for instance). Consequently, the conceptual challenge, as he saw it, was to take seriously the place-based nature of everyday life (i.e. the general need of all of us to have an adequate space of dependence) whilst reckoning with the increasingly distanciated ties that condition the fate of any given locality. Whereas some authors (e.g. Taylor, 1981) have considered the 'local' as the scale at which people construct their identities, Harvey has noted on several occasions that 'There are no ... grounds for considering face-to-face relations more pure [and] authentic ... than relations mediated across time and distance' (Harvey, 1993: 15).

This theme of a place-based but space-spanning politics among working-class and other oppressed groups became central to Harvey's 1990s writings. Many of Harvey's publications since his trenchant critique The Condition of Postmodernity (1989b) can be seen as a Marxian attempt to explain how and why 'good' forms of geographical difference might flourish - particularly the serially reprinted chapters 'Militant particularism and global ambition' and 'Class relations, social justice and the political geography of difference' (found together in Justice, Nature and the Geography of Difference [Harvey, 1996]). In the former, Harvey reflects on his disagreements with Teresa Hayter, co-editor of The Factory and the City (Harvey and Hayter, 1993):

The view that what is right and good from the standpoint of militant shop stewards in Cowley, is right and good for the city [of Oxford], and by extension for society at large is far too simplistic. Other levels and kinds of abstraction have to be deployed if socialism is to break out of its local bonds and become a viable alternative to capitalism. ... But there is something equally problematic about imposing a politics guided by abstractions upon people who have given of their lives and labour for many years in a particular way in a particular place. (ibid.: 23, emphasis added) 
Through a discussion of Raymond Williams's novels, Harvey tries to lay bare the problems and dilemmas confronting a 'both/and' politics that remains rooted in place yet can reach out positively across a wider landscape. Two loom large. The first is that because grassroots politics - workerist or otherwise - is inevitably conducted from place and is frequently about place, the question arises of how solidarity is to be constructed with others whose commitments, aspirations and goals are forged in quite different local contexts. For Harvey, the only way to bridge difference is to emphasize commonality (e.g. common interests, common enemies). But commonality does not speak for itself: it must be made visible and represented to those it aims to unite. In so doing, however, the risk becomes that commonality gets defined in such abstract terms (e.g. workers in place A and place B recognize that they share a 'working-class' identity) that the visceral, lived experiences that motivate political action become weakened or subsumed. As Miller (2004: 227) puts it:

Harvey and Williams call attention to the declining resonance of movement messages as they become further removed from the identities and everyday concerns of place-specific collectivities. This represents the central challenge that transnational [organizers] ... face. [They] ... must find ways to frame and reframe broad messages so they will resonate with a diverse and fluid array of collectivities in a wide range of place-specific and not so place-specific circumstances.

This links to a second problem, which is that the sorts of place-based interests and identities that often drive oppositional movements are forged under a social order (capitalist, racist, patriarchal) that is fundamentally oppressive. The challenge, then, is to forge translocal political action that can topple this order, rather than simply ameliorate its operations here and there. Aside from the logistical difficulties of this undertaking, Harvey also rightly notes how threatening it is to the very groups who have most to gain from making it happen, for it entails eradicating, in significant measure, the very sociogeographical differences that form the starting point for oppositional action in the first place. This is why, Harvey (op. cit.: 40) avers, both worker and TSM politics often acquire 'a conservative edge'.

Harvey's widely read essay 'Class relations, social justice and the political geography of difference' connects these issues of interlocal organizing with those of how social difference can be productively negotiated by oppositional movements. His starting point is to discuss a 1991 fire in a chicken-processing plant in a small North Carolina town (Hamlet). With the exit doors locked, 25 of the 200 employees died, of whom 18 were women and 12 African-Americans. Although he does not wish to collapse differences of gender and 'race' (or ethnicity) into class difference, Harvey does note that the failure to link all three in the Hamlet case - the response of the US left generally focused upon issues facing female and minority workers in the South, rather than upon issues facing all workers, regardless of gender or 'race' constituted a failure of political imagination and organizing. Like so many other towns in the US 'broiler belt', Hamlet had no tradition of trade unionism and its workers received minimal salaries and few benefits in a context where few other local employment opportunities presented themselves. As Harvey (ibid.: 338) argued, 'The commonality that cuts across race and gender lines in this instance is quite obviously that of class and it is not hard to see the immediate implication that a simple, traditional form of class politics could have protected the interests of women and minorities as well as those of white males'. Such a politics would, ideally, have been both local (e.g. by formally organizing Hamlet's wage workers regardless of job, gender, age or ethnicity) and translocal (e.g. established national unions putting pressure on federal and state regulators to discipline Imperial Foods, owner of the Hamlet plant). But, apropos Harvey's discussion of Williams, such organizing is by no means easy when so many different issues (of gender, 'race', etc.) have to be meaningfully expressed in a language (class) that has the capacity to be what Laclau and Mouffe (1985) called a 'hegemonic articulation'. Thus, Harvey's (op. cit.: 359) (re)definition of class in terms of 'positionality in relation to processes of capital accumulation' (rather than in terms of identity) ultimately ducks the important issues. Whilst it usefully reminds us that social differences irreducible to capital are nonetheless 'internalized' within the global labour force, it leaves unanswered all the important questions about precisely how class and identity politics, union and TSM politics, can be articulated both locally and translocally.

Even so, Harvey's thinking in this area has usefully identified some of the central issues for any politics that aims to organize across sociogeographical difference. True, some commentators (e.g. Braun, 1998) believe that Harvey ultimately wishes to subordinate non-class forms of social difference to class, whilst others (e.g. Routledge, 2003: 354) maintain that he wishes to transcend geographical difference. Even if these claims are valid, they do not detract from the fact that Harvey has highlighted some of the key tensions arising from the relational constitution of interests and identities that are lived locally and often expressed, in the first instance, in local terms. What, in his more recent book Spaces of Hope, he calls 'the 
work of synthesis' (Harvey, 2000: 72) is the difficult intellectual and practical work of conjoining sociogeographic differences even as, in the process, these differences are unlikely to survive intact. For Harvey, then, these differences must be conjoined because capitalism thrives on their apparent dissociation. But, at the same time, when oppositional groups undertake acts of translocal solidarity it is not in order to vanquish difference altogether. The fundamental question for Harvey is, therefore, this: what sorts of inter-place organizing can confront the totalizing powers of global capitalism whilst producing new forms of sociogeographical difference that are 'progressive' (in Massey's sense of being outward-looking) and not simply a new means for existing power relations to be instantiated?

\section{Doreen Massey: The Politics of Place Unbound}

Notwithstanding Justice, Nature and the Geography of Difference, many of Doreen Massey's influential writings on place, space and politics are more abstract than either Cox's or Harvey's. This partly explains their appeal. By writing in very philosophical but relatively jargon-free terms, Massey has managed to shape research agendas across critical human geography as a whole (and, indeed, beyond it). Another reason why her work has enjoyed a wide appeal is that it is heterodox: unlike Cox and Harvey, her Marxism has given way to post- and non-Marxist modes of thought (for instance, the work of Ernesto Laclau and Chantal Mouffe has been an important influence on her).

In a recent reflection on over a decade of her writing on place, Massey has summarized her agenda as follows: 'Thinking place relationally was designed to intervene in a charged political arena. The aim initially was to combat localist or nationalist claims to place based on eternal, essential and ... exclusive characteristics of belonging: to retain, while reformulating, an appreciation of the specific and the distinctive while refusing the parochial' (Massey, 2004: 6). Like Cox and Harvey, then, Massey has long taken issue with Cartesian conceptions of place (what she calls 'the billiard ball world of an essentialist Newtonianism' [Massey, 1999a: 38]) and the politics they can mandate. However, she advocates a more overdetermined understanding of how geographical difference is produced out of geographical interconnectivity across space. As she put it in Power-Geometries and the Politics of Space-Time:

.. 'places' may be imagined as particular articulations of ... social relations, including local relations 'within' the place and those many connections that stretch way beyond it. ... This is a notion of place where specificity (local uniqueness, a sense of place) derives not from some mythical internal roots nor from a history of relative isolation - now to be disrupted by globalization - but precisely from the absolute particularity of the mixture of influences found there. (ibid.: 22)

In an indirect swipe at what she argues is the sort of 'muscular' Marxism favoured by Cox and Harvey, she has contrasted this conception of place to one underpinned by 'a closed holism ... where there is no space for anything new' (ibid.: 38). But her particular conception of geographical difference is ranged against other targets too, not just the antinomies of Cartesian (non-relational) and holistic (relational but closed) understandings. It is also forged in opposition to a powerful geographical imaginary expressed in hegemonic uses of the term 'globalization': what she calls an 'aspatial imaginary' in which geographical difference is temporalized such that 'underdeveloped' places in the 'Third World' are seen to be 'behind' the West yet potentially able to become 'like us'. Thus, as the champions of neo-liberal globalization would have it, those localities and nations who have yet to benefit from free trade soon will, for their temporalized differences will eventually be erased as globalization leads to a convergence around Western levels of development.

Massey's three-pronged critique of certain geographical imaginations is thus undertaken in the name of 'a different kind of difference' (Massey, 1999b: 281): what she rather tendentiously calls 'real difference' (op. cit.: 21), by which she means the contingent, singular and unpredictable geographical differences that continually emerge out of the many connections (some yet to be made, some never to be made) that wire different places to different other places. What has all this got to do with politics? A great deal. In the first place, it is by no means easy for local actors to agree upon the sorts of difference (both 'objective' and 'subjective') that should be promoted into the future. The fact of geographical propinquity, Massey has rightly argued, does not produce any ready consensus about what local interests and identities are or ought to be. After all, many twenty-first-century places are intensely differentiated internally (in social and land-use terms) and so, often, there is local struggle over what sorts of place-projects are to be favoured in any given locality (Massey, 2004: 7).

Second, like Cox and Harvey, Massey insists that a 'politics of propinquity' can only be undertaken in relation to a 'politics of connectivity' (the terms are those of Amin [2004]). This follows from the ontological fact that contemporary places are more 
than they contain. This politics is also contested, since certain local actors will favour, say a competitive inter-place politics whilst others might prefer a more cooperative politics. Moreover, because the precise network of translocal connections that constitute a place varies from locality to locality, the content and form of such a connective politics will vary too. This means that grassroots attempts to challenge the wider 'power-geometries' that constitute place both objectively and subjectively will be immensely varied and complex. For Massey, this is more than a case of identifying the broad 'commonalities that cross-cut difference'. Because the precise nature of these commonalities will, themselves, vary depending on the cluster of places involved, the politics of organizing across difference becomes exceedingly complicated. Hence, as she puts it, 'one implication of the ... inequality inherent within capitalist globalization is that the local relation to the global will also vary, and in consequence so too will the coordinates of any potential local politics of challenging that globalization. Moreover, "challenging globalization" might precisely in consequence mean challenging, rather than defending, certain ... places' (op. cit.: 13).

In sum, Massey advocates a move from a 'politics of place' to a 'politics in place'. As Amin (2002, 2004) explains, the latter is a 'non-territorial politics' that involves the negotiation of difference both within and between places whereas the former is 'a politics of place in which relations within localities are cast as good and felt, separate from bad and[/or] remote external happenings' (Amin, 2002: 388). This links to the above-mentioned problematization of just how 'common' inter-place goals, enemies or aspirations can be when oppositional groups are concerned. Miller (2004: 235) summarizes this well: 'different bases of spatial interaction produce different kinds of collective [aims] ... which, in turn, present different mobilization challenges'.

As we have already noted, the fact that Massey's writings on place are often highly philosophical helps to explain their wide influence: many different human geographers have been able to appropriate her ideas for their specific needs. But their abstract nature is also their weakness. As with Cox and Harvey's writings, Massey's seem to us to avoid most of the crucial questions one might reasonably want to answer about the politics of oppositional groups organizing across difference. For instance, exactly how can place-based groups forge connections with distant others? How and with what specific effects are place differences transformed through acts of interlocal solidarity? What criteria should be used to evaluate these transformations? Are 'progressive' and 'regressive' place projects distinguishable in practice or can even the most 'extrovert' place politics lead to unintended consequences that compromise the interests of distant others? We could go on, but the point is clear.

To summarize, then, Kevin Cox, David Harvey and Doreen Massey have developed among the best-known conceptions of geographical politics - ones in which the thematic of place difference looms large, where interlocal organizing is deemed to be essential, and where the problems of engaging constructively across space are fully acknowledged. It is no surprise that critical geographers casting around for frameworks to approach recent experiments in translocal organizing have, in part, drawn upon one or more of these three theorists' work. Whereas Cox and Harvey have commended a scalar framework as the appropriate way to understand inter-place connections (see Cox, 1998; Harvey, 1996: 352-4; 2000: 75-7), Massey has favoured network metaphors and has largely avoided the 'topographical' language of scale - although all three have largely left it to others to flesh out empirically how these connections might be made.

The 'divide' between scalar ('topographical') and network ('topological') approaches to 'crossing difference', however, is not always easy to divine - this despite some commentators (e.g. Amin, 2002, 2004) emphasizing its signal importance for analysis and practice. Such difficulty is evident in the numerous empirically grounded studies of both the NLI and TSMs that use the terms 'scale' and 'networks' interchangeably (e.g. Routledge's [2003] essay on global 'anti-capitalist' movements; see also Murdoch and Marsden, 1995). This suggests that notions of scale and network are not simply 'reflections' of the varied translocal movements whose actions are being analysed. Rather, they are also notions constructed actively within the academic community: ones designed to inform the 'real world' realities they describe (Flint's point) and to dictate the terms of debate within a community of critical geographers subject to the mundane imperatives of promotion, tenure and professional recognition. The differences between scalar and network imaginaries of translocal connectivity are thus part of, without being reducible to, academic struggles for citations and influence in relation to one of critical geography's 'hot topics': the topic of transnational resistance to transnationally organized relations of power. For some commentators (notably Marston and Jones, 2005), the differences are irreducible and upon them hang important issues of real-world analysis and political possibility. We are not so sure. Our tack here is simply to present both sides of the argument, since a properly comparative analysis and/or synthesis has barely been attempted by any of the authors whose work we discuss in the pages to come. 


\section{THE POLITICS OF GEOGRAPHICAL SCALE: THE NEW LABOUR INTERNATIONALISM AND BEYOND}

The so-called 'new labour internationalism' is new in relative but not absolute terms. Beginning over a century ago, wage workers in several Western countries have made concerted efforts to organize their interests and actions across national borders. Despite some notable successes, however, the Marxian dictum 'Workers of all lands unite!' tended to be honoured in the breach throughout most of the twentieth century. Relatively well-off Western wage workers mostly accented their national interests and were organized through strong national trade unions. By contrast, many workers in the developing world remained non-unionized. Meanwhile, the Cold War meant that 'second world' workers were separated from their capitalist equivalents on ideological grounds. Given this history, then, the NLI is new in two ways. First, quantitatively speaking, the last fifteen years or so have seen a fairly sharp increase in the number of translocal worker campaigns. Second, many of these campaigns have breached the 'divides' between the developed world, the former communist countries and the developing world.

A good deal of the geographical literature on the NLI has applied and developed theoretical ideas about geographical scale and scale politics. This is what makes it distinctive. However, whilst the NLI has received much attention from non-geographers such as Peter Waterman, Ronaldo Munck and Richard Hyman, such authors have rarely thematized geographical difference explicitly and have tended towards a thin conception of spatial scale. In contrast, a number of geographers have expressly linked scale to questions of the production and transcendence of geographical difference. Most notably, Neil Smith (1992) has argued that 'the local' is one of several scales at which geographical difference is produced, such that 'crossing difference' is a multiscalar activity and not simply a 'jump' from the local to an undifferentiated space of the global. Despite Smith's call for a multiscalar sensibility to issues of crossing difference, much of the geographical research into the NLI has nevertheless had a strong local sensibility, for the reasons that Cox explains so well: that all production and reproduction necessarily occurs in place so that worker politics, whatever else they are about, must be about the local in some measure, even as they may also be about the extra-local. The key issue, then, becomes, what sorts of links at what geographical scales can further local interests without compromising those of other constituencies enrolled in these linkages? In relation to the NLI, we can therefore pose the questions: how have contemporary wage-workers organized themselves across space, why and with what outcomes?; and what is 'political' about the NLI? To answer these questions we need first to summarize the theoretical debates on geographical scale and scale politics. Since these debates have been reviewed elsewhere (see Herod and Wright, 2002; Howitt, 2003), we offer a highly stenographic account here.

\section{Theorizing Geographical Scale}

As we have intimated above, issues of geographical scale and the politics thereof began to impact geographical theorizing in the 1980s. Two of the key discussions of scale came from Smith and Taylor, though these writers had quite different approaches to the topic. For his part, Taylor (1981, 1982) outlined a vision in which particular scales of social life took on specific roles under capitalism; he viewed the global scale as that at which capitalism operated in toto, whereas the national and local scales were those at which, respectively, ideology (primarily that of nationalism) operated and everyday life was lived. Smith (1984), on the other hand, focused not so much upon the functions of different scales within the operation of capitalism but upon how scales were actively produced under capitalism. Hence, he viewed the global scale as the product of the universalization of the wage-labour form, whereas the national scale was solidified by the need for nationally organized capitalists to regulate 'unfair' competition among themselves and to defend their interests against those of other nationally organized capitalists, the regional scale reflected the territorial division of labour (initially based upon the natural distribution of the Earth's resources but later reworked by processes of capitalist accumulation), and the urban scale was an expression of the spatial extent of the daily labour market and of commuting patterns. Writing at the height of the 1980s debate concerning the 'new regional geography', Smith's take on scales reflected not only his Marxist analysis of why the capitalist landscape seemed to be pockmarked at a number of different spatial resolutions (the urban, the regional, the national, the global) by the processes of spatially uneven development, but also a reaction to the neo-Kantian Hartshornian 'traditional' regional geography in which space was conceptualized as something that could simply be carved up into larger or smaller bits to suit the whims of the individual researcher, a carving-up that paid no attention to the 'necessary' spatial relationships between particular places (e.g. see Smith's [1989] critique of Hartshorne).

If such early theoretical forays into the politics of geographical scale were marked by a certain functionalism and capital-centrism, the development of what has come to be called 'labour geography' in the early 1990s was tied up, in part, with a growing 
concern to theorize the politically contested nature of the production of the geographical scales of social life. Place, this literature argued, matters to workers immensely - even migrants are placebased in order to secure a living. However, acting in place is often insufficient for workers to realize their material and emotional interests. Rather, they invariably must cross space to do so. For example, unions may seek to develop national contracts with spatially uniform wage rates to prevent capital from playing workers in different communities against each other, whereas capital may prefer decentralized wage bargaining to take advantage of the landscape's economic and institutional and legal differentiation to 'whipsaw' workers. Equally, lest the implication be drawn that particular scales of organization are theorized as being somehow inherently more beneficial to capital whereas others are to labour, it is important to recognize that some firms may, for similar reasons, prefer to negotiate at a national scale whilst some workers prefer to do so locally: high-wage firms may seek a national agreement so that they are not outbid by their low-wage competitors, whilst workers may favour negotiating locally to take advantage of their position in the labour market.

Central in all this, though, is an implicit understanding that the construction of scale is a way to negotiate spatial difference, such that at times the construction of scale revolves around efforts to minimize difference between places (as when unions successfully negotiate nationally uniform wage rates) and at others it involves actually stressing difference (as when groups of workers construct scales of organization that emphasize variations in local conditions and/or seek to take advantage of them). Furthermore, such an engagement with the spatiality of difference can have significant impacts upon how unions' organizational structures themselves develop. Hence, Southall (1988) notes that in Britain the relative geographical mobility of different groups of workers contributed to the emergence of particular types of union consciousnesses and political structure in different places and industries. Thus, in the mining industry, the particularities of geology meant that miners needed locally specific skills to work successfully in different pits (coal seams in the very same region can vary immensely, let alone between regions), a reality that both discouraged their mobility and encouraged the development of localist consciousness based on the pit community.

\section{The New Labour Internationalism and Beyond}

Significant research effort has been expended in trying to understand how workers and their organizations overcome spatial barriers that divide them so that they might present a unified face to their employers. Growing concerns with 'neo-liberal globalization' in the 1990s seemed to make efforts to develop solidarity links (especially international ones) take on greater urgency, both within the labour movement itself and within that part of the academy that was labour-sympathetic. Thus, the more trade unionists called for greater international solidarity to confront the power of corporations, the more critical human geographers seemed to be interested in the geographical conundrums that such efforts might both face and spawn (e.g. Herod, 1995, 1997; Castree, 2000; Sadler, 2000; Wills, 2002a). Much of this work focused upon either the use of formal trade union organizations such as the International Confederation of Free Trade Unions (ICFTU), various Global Union Federations (GUFs) and European Works Councils all of which, significantly, have particular and formalized spatialities to them - or upon less formal worksite-to-worksite connections that often develop in response to specific needs (such as the threatened closure of particular factories).

There are myriad examples within the critical geographical literature examining labour's political responses to the new spatiality of global capitalism, but, at the risk of charges of self-promotion, we will use the work of one of us to explore here briefly a number of issues relating to workers' construction of new geographic scales of organization. One of the earliest pieces to consider an international solidarity campaign confronting a globally organized corporation was Herod's (1995) investigation of a dispute involving aluminium workers in Ravenswood, West Virginia. In October 1990, some 1,800 members of United Steelworkers of America Local 5668 were locked out of their plant in a dispute over health and safety and pension issues. The plant had recently been purchased by an international consortium of investors, following which workplace injuries at the plant had soared, with five workers killed within eighteen months of the new managers taking over. When the union decided to make health and safety a central issue in upcoming contract negotiations, the company locked the unionists out and brought in non-union 'replacement' workers. Local 5668 officials soon discovered that the plant's new owners were tied to international commodities trader and fugitive from US authorities Marc Rich, who was living in Zug, Switzerland. Upon learning this, they worked with representatives of their national union, of the AFL-CIO, and of a number of international trade union organizations most notably two GUFs, the International Metalworkers' Federation (the 'other' IMF!) and the International Confederation of Chemical, Energy, Mine, and General Workers' Unions (ICEM) - to develop links with unions and workers abroad, unions and workers who then brought pressure to 
bear upon the constituent elements of Rich's multibillion-dollar global empire. As a result of such transnational strategies, after some twenty months the Ravenswood workers were successful in forcing Rich to permit the locked-out workers to return to work.

Most observers, we think, would view the Ravenswood campaign as a textbook example of how workers might transcend geographical difference and distance to challenge capitalist social relations by organizing internationally for the purposes of protecting workers in a particular place, in this case a small town in rural Appalachia. Such instances of workers engaging in international solidarity, however, raise important issues for efforts to construct (and to provide a narrative about) what political geographers might take to be a spatially and scalar-sensitive, anti-capitalist political project. Specifically, there has been a tendency in orthodox Marxist accounts to assume that instances of workers constructing scales of organization that stretch beyond the local is automatically 'progressive' politically, for it is taken to represent a great proletarian conjunction that has overcome the spatial barriers and allegiances to place that so often divide workers.

However, as Johns (1998) notes, such an assumption fails to appreciate the subtleties of geographical interconnectivity and difference. Thus, some international solidarity campaigns are clearly waged to challenge directly capitalist social relations, as when workers in one place (such as Switzerland) act to help those in other places (Ravenswood) without any expectation that they themselves will gain any immediate benefits - a practice that Johns calls 'transformatory' solidarity. However, it is important to recognize that what may, on the surface, appear to be altruistic reasons for instigating a solidarity campaign (the desire to help workers overseas increase their wages) can sometimes be more about defending particular privileged places in the global economy than challenging capitalist social relations: by increasing the wages of workers overseas, particularly those in developing countries, those workers' communities become less attractive to capital that may otherwise choose to flee the global North. Paradoxically, this kind of trans-spatial solidarity action what Johns calls 'accommodationist solidarity' actually divides workers in space under the guise of uniting them across space, a phenomenon that illustrates the challenges of realizing the delicate interplay of 'progressive' forms of worker localism with the kinds of wider inter-place solidarities sketched by Cox, Harvey and Massey.

In discussing workers' political praxis it is important to understand not just the reasons for which workers seek to cross difference but also how discourses of scale are implicated in different models of organizing. Thus the model used in the type of international solidarity organizing outlined above - whether that be for transformatory or accommodationist purposes - is typically one built upon a nested hierarchy of discrete levels, where pleas for help are passed up the organizational ladder domestically and then back down it overseas. In the US and Britain this has been a fairly common approach to organizing, especially because in the twentieth century unions often engaged fulltime professional organizers who worked out of the union's national headquarters and served as the conduits between local branch unions and the appropriate international labour institutions; the Ravenswood local, for instance, worked up the chain of its union's organization, with its international union in Pittsburgh and its national federation (the AFL-CIO) in Washington, DC, engaging with international union organizations such as the ICEM and the ICFTU, who themselves made contacts with local unions in various countries around the world who agreed to help the Ravenswood unionists. Implicitly, then, this model is one in which labour organizers have viewed their scalar organization in terms both hierarchical and areal, focusing upon what Bruno Latour (1996: 370) calls 'notions of levels, layers, territories, [and] spheres', such that the practice of developing geographically extended solidarity is seen as a process of linking one discrete level (the local) to others (the regional, the national, the global) and back again through a quite hierarchically structured set of organizational linkages. Although the disintegration of highly vertically integrated firms and the growth of 'networked firms' have encouraged some unions recently to explore 'network-based bargaining' (see Wial, 1994; Herod, 2006), it is fair to say that during the past half century at least international solidarity actions on the part of unionized workers have typically incorporated fairly hierarchical spatial imaginaries.

In concluding this section, we would like to bring the issue back to that of place and organizing within the context of geographical difference. How we understand place (in its objective and subjective dimensions) will have implications for how we comprehend and portray scale: are scalar relations about the connections between points in a network or are they about the ways in which different areal units are considered to be linked together in some spatial gestalt? Moreover, without an appreciation of the language of scale, what does it even mean to talk of 'place'? Where, in fact, does one place end and another begin? In areal approaches to scale this is relatively easy to determine, but in a fibrous, thread-like, wiry, stringy, ropy and capillary Latourian (or Masseyan) world it becomes much more difficult: Are places simply the intersections of a network or are they something different? Where, exactly, does a place end if it is viewed as an intersection within a network (given 
that, mathematically speaking, points of intersection would be infinitely small)? If the world is stringy, is place merely one end of this piece of string and, if so, what is at the other end? Equally, what does it mean to talk about 'organizing across space' and 'organizing across difference' in light of the discussion above? What does workers' construction of new scales of organization so as to overcome the distances between them mean for issues of difference? For sure, an areal view of scale clearly incorporates within it a sense that constructing new scales of organization is a process either of eradicating, 'suspending' or of amplifying differences between places; developing a national wage rate is clearly about ensuring uniformity of remuneration across the national economic space, no matter where workers labour, whilst engaging in local bargaining is about taking advantage of the differentiation of the landscape and, perhaps, even intensifying it. But what about the issue of networked approaches to scale? Do these approaches to scale necessarily imply the same kinds of eradication, suspension and/or generation of difference? Or do they imply something different? It is to questions such as these that we now turn, even as we acknowledge that human geographers have yet to provide satisfactory answers to them.

\section{TRANSNATIONAL SOCIAL MOVEMENTS: THE POLITICS OF NETWORKED SOLIDARITY}

In this section we examine the research of those inclined to conceive of TSMs in network terms. The geographical analysis of TSMs has mushroomed in the wake of the now-famous Zapatistas struggle in southern Mexico and the anti-capitalist protests in Seattle, Prague, Genoa and elsewhere. Unlike Hardt and Negri's (2000) celebrated but abstract account of 'the multitude', this research accents the uneven topology of inter-place organizing. In part, this is because of the disciplinary influence of Massey's 'fibrous' conception of place, going back over a decade. TSMs have diverse constituencies and agendas, notwithstanding their coming together in what Routledge (2003) calls 'convergence spaces'. They include indigenous peoples' organizations, advocacy groups for women and children, anti-nuclear bodies, human rights groups and environmental organizations, among others (see Cohen and Rai, 2000). Despite the prevalence of network metaphors of organization and political activity among TSMs, geographers have approached the study of these movements from a diversity of theoretical perspectives and concerns. Thus, Merrifield (2002) has persuasively drawn on the writings of Lefebvre on everyday life to engage with the alternative forms of urbanism and protest deployed through the Seattle protests, whilst Glassman (2003: 513) has explored how activists struggling against corporate globalization (e.g. through opposition to river damming in Thailand) have 'jumped scales' and utilized various international connections to improve 'their visibility and strengthen their prospects for success'. Glassman is one of a number of writers who have adopted scalar thinking and conceptual metaphors to make sense of non-trade-union resistance to neo-liberal globalization (see also Smith, 2000; Wainwright et al., 2000; Wills, 2002b; Ashman, 2004; Mamadouh et al., 2004; Miller, 2004; Novelli, 2004). As already noted, other geographers have suggested that such scalar analyses of political activity have serious drawbacks (Amin, 2002; Gibson-Graham, 2002; Massey, 2005).

\section{Scales and Networks: An Ideal-Typical Comparison}

Before discussing network analyses of TSMs in any detail, it is useful to delineate four key differences between these accounts of geographically stretched soldarities and scalar approaches. The complicating factor here is that various authors use the terms 'scale' and 'network' interchangeably to refer to quite different things. However, rather than playing the role of disciplinary enforcers by suggesting that some uses of these terms are appropriate whilst others are not, here we explore how the differences between the two approaches to geographical politics have been presented by advocates of network approaches (such as Ash Amin), for to do so throws light on how different authors conceive of the practice and implications of crossing difference.

First, writers like Amin see relations between places and networks as co-constituted rather than privileging boundaries between scales, or counterposing the local and global. Second, according to their advocates, networked theories develop a more generative role for place-based political activity. In these accounts, such activity becomes reconfigured as always already the product of different trajectories and involved in negotiating spatially stretched relations of power. In this regard, place-based movements can become the means through which transnational articulations are made and crafted rather than bounded militant particularisms (see Featherstone, 2005). Third, it has been argued that networked accounts see solidarities as constituted by dynamic trajectories and identities, rather than (relatively) fixed interests. This can account for how new political possibilities and subjectivities are produced through the coming together of different political trajectories. Finally, some authors maintain that network 
approaches challenge dominant accounts of what counts as political subjects. In particular, they challenge human-centred accounts of the political that see the social as the dominant actor (Murdoch, 1998; Hinchliffe, 2000; Braun and Disch, 2002; Featherstone, 2004). This reconfigures the activity of solidarities as being about bringing together articulations of humans and non-humans and intervening in the constitution of networks within and among places.

Scalar and network approaches, however, are not just about different ways of making sense of political movements. Rather, they also have markedly different conceptions of politics, both cognitively and normatively (Featherstone, 2003). Hence, whilst scalar approaches often follow Harvey's (1996: 400) argument that class is the key node around which solidarities/differences can be articulated, network approaches tend to trace how sociogeographical differences in a more-thancapitalist world are both made and co-related. Most specifically, they have arisen out of political engagements that have been intensely suspicious of hierarchies and, as such, are wary of Marxian arguments that class should be prioritized as the social division that is 'first among equals' when it comes to political identity and struggle. Instead, they see networked forms of political activity as ways of generating non-hierarchical forms of organization. Consequently, networks such as the Internet have been celebrated as a key metaphor for the kinds of non-hierarchical forms of mobilization that are central to the political practices and identities of many activists involved in counter-globalization movements (see Graeber, 2002; Klein, 2002; Hardt and Negri, 2004: 288). The political inclination of these accounts and movements is generally hostile to some of the implicit forms of vanguardism seen to be present in the analyses of political economic geographers like Harvey and Smith. Finally, network accounts, through following political activity rather than confining it into particular scales, can suggest more generous accounts of the relations between place-based politics and political imaginaries, according to authors like Amin. Rather than place-based political action being neatly separate from 'abstract' ideas, these approaches suggest much more dynamic and generative relations between place-based activity and networks. This opens up possibilities for different assessments of what constitutes political agency or effectiveness.

\section{Place and the Making of Transnational Networks}

In a recent paper on the geographies of transnational social movements, Byron Miller (2004: 224) has argued that TSMs represent a 'fundamental shift away from place-based forms of political organizing and towards transnational mobilization networks'. Although such a counterposing of 'place-based activity' and the formation of transnational mobilizations is fairly common in the literature, from a network point of view this is problematic, for one of the key insights of conceptualizing TSMs in network terms has been a focus on how places and networks are co-constituted. Hence, the growing significance of transnational forms of organizing does not inevitably mean an erosion of the importance of place, nor does it imply (as some have suggested) that resistance now inhabits a smooth and undifferentiated space of opposition to neo-liberalism (Hardt and Negri, 2000, 2004).

Indeed, recent work in geography on the formation of transnational networks of mobilization has sought to highlight the mutual constitution of place-based political activity and transnational networks in three main ways. First, it has emphazised how transnational mobilization is constituted through particular physical (local) sites (Routledge, 2003; Amin, 2004; Bunnell and Nah, 2004; Townsend et al., 2004; Featherstone, 2005 and this volume). Second, it has demonstrated how place-based political identities can be actively reshaped and reworked through involvement in spatially stretched networks of activity and can exert pressure on the formation of transnational solidarities through such networks (Oza, 2001; Slater, 2002; Featherstone, 2003; Massey, 2005). Finally, whether acting alone or together, many individual TSMs put issues of place and locality at the core of their agenda. This is particularly the case with indigenous peoples' movements, where translocal action is often a means for enacting resolutely local struggles over land and natural resources (Castree, 2004; see also Escobar, 2001; Perreault, 2003; Oslender, 2004: 958). At the limit (as we suggested in the previous section), network approaches, then, raise the vexing question of what, precisely, is 'place' (point? location? locale?).

These arguments about the co-constitution of place and transnational networks can be illustrated briefly through the activity of the European Campaign for Nuclear Disarmament (ENDS), which managed to construct spaces of organizing that cut across the entrenched geopolitical divisions and differences of the Cold War. Following the networks formed through ENDS's political activity illustrates how network approaches can foreground the relationships between place and transnational forms of mobilization. Formed in response to the late 1970 s/early 1980 s resurgence of Cold War hostilities, the ENDS campaign brought together peace activists from both the Eastern bloc and Western and Northern Europe to campaign for a Europe free of nuclear weapon 
deployment. This was a particularly urgent task, as Europe was the main proposed 'theatre of war' in the event of any nuclear exchange. Significantly, ENDS was an attempt to organize across the crude spatial division of Europe into 'East' and 'West'. Drawing heavily on the intellectual and political projects of the New Left, ENDS, then, attempted to develop political imaginaries that reunited Europe through common struggles for peace and democracy (though the Europeanfocused nature of the campaign had its critics; see Davis, 1982).

For the purposes of this discussion, the following elements of ENDS's activity and spaces of politics are particularly salient and demonstrate how political networks and place-based political activity can be mutually constitutive. First, ENDS represented an explicit attempt to construct transnational networks and articulations of opposition to the Cold War to bring together peace activists from both sides of the Iron Curtain. As the ENDS Appeal of 1980 implored:

We appeal to our friends in Europe, of every faith and persuasion, to consider urgently the ways in which we can work together for these common objectives. We envisage a European-wide campaign, in which every kind of exchange takes place; in which representatives of different nations and opinions confer and co-ordinate their activities; and in which less formal exchanges, between universities, churches, women's organizations, trade unions, youth organizations, professional groups and individuals, take place with the object of promoting a common object: to free all of Europe from nuclear weapons. (ENDS, 1980: 225)

Through bringing together different activists from both Eastern and Western Europe, ENDS sought to contest the spatial imaginaries of Cold War geopolitics and to develop a critique of the polarizing ideological work upon which the Cold War depended.

Second, the activities of ENDS produced an 'actually existing alternative' to that which it criticized by producing spaces for different political trajectories to come together. This allowed dissidents from Eastern Europe, such as Adam Michnik, Rudolf Bahro and Roy Medvedev, to exchange and debate ideas with figures from the peace movement and the New Left in Western and Northern Europe (see Bahro, 1982; Medvedev and Medvedev, 1982; for a more critical Eastern European perspective, see Racek, 1982). Through these practices, ENDS's networks brought together political activists from distinctive places and political traditions, including: the independent Marxism of Rudolf Bahro, which was formed through bitter critique of 'actually existing socialism' (Bahro, 1977); the experiments with radical feminist organizing for peace that culminated in the peace camp at Greenham Common (see Cook and Kirk, 1983; Cresswell, 1996); and the distinctively 'English' New Left politics of E. P. Thompson (see Thompson, 1980, 1982). Through exchanges, debates, conflicts and arguments between activists from different places, ENDS produced a transnational political movement, not so much through activity that might be defined as 'jumping scales' (which would imply that such activists had captured, say, the national state in various countries) as by bringing together dissidents and peace activists in different countries through common networks and dialogues.

Here we can see a further way in which place matters in the construction of solidarities. Whereas distinct, place-related interests and identities are often seen as barriers to be overcome through political organizing, places can also be significant as the sites where different political trajectories are brought together for, as Latour reminds us, networks remain local at all points (Latour, 1993: 117-20). The activity of ENDS, then, was a networked achievement or a fabricated articulation of sites. These articulations were produced through spaces such as offices and homes in England, often under security service surveillance, and the flats of dissidents and peace activists in Prague and Budapest, such as those visited by Dorothy and E. P. Thompson (Palmer, 1994: 134-5). Equally, the annual ENDS conventions were events that brought together in specific places activists from all over Europe, though this was commonly a fractious, contested and difficult process (Kaldor, 2003: 63). This phenomenon emphasizes that 'what is involved' in constituting the relationships between the 'local' and 'global' 'is an immensely difficult, always grounded, and "local" [ ... ] negotiation' (Massey, 2005: 182; see also GibsonGraham, 2002) that calls into question the stark counterposition of local particularist struggles and global universalist ones present in Harvey's (1996) accounts of the relations between local and global struggles.

The fact that these alliances were productive of new political spaces, identities and possibilities shows how place-based identities do not remain static and unchanged through involvement in transnational political networks but can be challenged, unsettled and reconfigured through such activity. The networks produced through articulations of these different place-based struggles and political cultures were also significant, as ENDS allowed dissidents in Eastern Europe to make connections with each other, albeit mediated through Western European cities such as London and Stockholm (Kaldor, 2003). As a result, the networks that ENDS produced and generated popularized across 
Europe discourses and repertoires of activity associated with what has now become termed 'global civil society'.

In this section, then, we have sought to show how geographers and others have approached TSMs using a variety of analytical perspectives. Although it is an open question as to whether there is a material networked spatiality to TSMs that demands that network approaches should necessarily be used for analyses of such movements, advocates of network approaches have certainly shown that such approaches have a number of strengths that are worth considering seriously including the fact that they are alive to the productive and multiple character of political activity and resonate with the anti-hierarchical forms of organization that characterize many TSMs, whilst they are suggestive of the co-production of placebased political identities and transnational networks. Whether such approaches can generate the forms of political prescription and strategic direction demanded by some is, however, another question.

\section{CONCLUSION}

In our review of geographic research into the NLI and TSMs we have considered two ways of analysing the politics of organizing difference, all the while accenting the important of place as both a condition and an outcome of translocal solidarity. As we have seen, the research explored in this chapter has been conducted in response to the recent florescence of 'borderless' organizing by workers and social movements worldwide. A major theme of this research is how and with what consequences 'local difference' is an outcome and condition of wider geographical connectivities. But this research is not simply a reflection of the 'real world' actualities of which it seeks to make sense. Rather, the language used to describe such campaigns also has the power to help shape them materially, in much the same way as neo-liberal discourses of globalization as an unstoppable force encourage the adoption of policies that dismantle barriers to global capital flows (what we might call the 'self-fulfilling prophecy' phenomenon). However, as Miller (2004: 224) has argued - rightly, in our view - 'the work of building an emancipatory world order has just begun'. For all their media visibility, protests in places like Seattle are no substitute for the patient, complex work of challenging transnational power relations without effacing the geographical differences that such challenges attempt to unite in joint undertakings. In this light, we might reasonably ask what insights the research reviewed in this chapter yields for activists seeking to make transborder resistance truly effective. Our answer, regrettably, is 'very few at this stage' (contra Flint's judgement). There are two reasons why.

First, though many of the studies reviewed in this chapter yield concrete insights into how, why and with what effects borderless solidarity occurs, it seems to us that a key task remains: to parse these insights across the literature as a whole so that some clear lessons can be drawn about aims, strategies and outcomes (Marston and Jones, 2005, remains almost a lone effort in this regard). This involves more than identifying the differences and commonalities between scalar and network approaches. More specifically, it involves synthesizing the literature so that we can answer the following sorts of highly specific questions: What is the most effective basis for otherwise place-based constituencies to unite? Is it around common identities, common enemies, common goals, all three or something else? What sorts of resources are required to make transnational organizing more than an unstable, fleeting phenomenon? What sorts of tactics lead (or do not lead) to the goals of those involved in the NLI and TSMs being realized? What are the unintended consequences of the NLI and TSMs? We could go on, but the point is clear enough. Individual studies of the NLI and TSMs answer these and other questions, but the wider lessons to be drawn remain unclear.

Second, Andrew Kirby (2002) has noted that the 'comfortable heuristics around which much academic discourse ... revolve[s] ... [do] not represent [the] ways that most people outside the academy think'. We agree. We earlier made fleeting reference to struggles for recognition within the community of critical geographers as one factor explaining why the rival discourses of scale and networks have risen to prominence in recent years. If Colin Flint's vision is to be realized, the researchers whose work has been discussed here (our own included) will have to make greater efforts to speak a language that activists can understand. This will, among other things, involve rendering arcane disputes about scale politics and networked solidarity into useful insights for actors seeking to make common cause across the relative and absolute distances that separate them. Despite new-found excitement about the idea of 'public geographies', it is fair to say that much of the research reviewed here remains encased in books and journals where only the cognoscenti can access it.

\section{REFERENCES}

Agnew, J.A. (1987) Place and Politics. London: Allen \& Unwin. Amin, A. (2002) 'Spatialities of globalization', Environment and Planning A, 34(3): 385-99.

Amin, A. (2004) 'Regions unbound: towards a new politics of place', Geografiska Annaler B, 86(1): 33-44. 
Ashman, S. (2004) 'Resistance to neoliberal globalization: a case of militant particularism?', Politics, 24(2): 143-53.

Bahro, R. (1977) The Alternative in Eastern Europe. London: Verso.

Bahro, R. (1982) 'A new approach for the peace movement in Germany', in E.P. Thompson et al., Exterminism and Cold War. London: Verso, pp. 87-116.

Braun, B. (1998) 'The politics of possibility without the possibility of politics?', Annals of the Association of American Geographers, 88(4): 712-18.

Braun, B. and Disch, L. (2002) 'Radical democracy's "modern constitution", Environment and Planning D: Society and Space, 20: 505-11.

Bunnell, T. and Nah, A. (2004) 'Counter-global cases for places: contesting displacement in globalizing Kuala Lumpur Metropolitan Area', Urban Studies, 41(12): 2447-67.

Castree, N. (2000) 'Geographic scale and grass-roots internationalism', Economic Geography, 76(2): 272-92.

Castree, N. (2004) 'Differential geographies', Political Geography, 22(9): 1012-29.

Cohen, R. and Rai, S. (eds) (2000) Global Social Movements. London: Athlone Press.

Cook, A. and Kirk, G. (1983) Greenham Women Everywhere: Dreams, Ideas and Actions from the Women's Peace Movement. London: Pluto Press.

Cox, K.R. (1998) 'Spaces of dependence, spaces of engagement and the politics of scale', Political Geography, 17(1): $1-23$.

Cox, K.R. (2005) 'Local:global', in P. Cloke and R. Johnston (eds), Spaces of Geographical Thought. London: Sage, pp. 175-98.

Cox, K.R. and Mair, A. (1988) 'Locality and community in the politics of local economic development'. Annals of the Association of American Geographers, 78: 307-25.

Cresswell, T. (1996) In Place/Out of Place. Minneapolis: Minnesota University Press.

Davis, M. (1982) 'Nuclear imperialism and extended deterrence', in E.P. Thompson et al., Exterminism and Cold War. London: Verso, pp. 35-64.

European Campaign for Nuclear Disarmament (1980) 'Appeal for European Nuclear Disarmament', in E.P. Thompson and D. Smith (eds), Protest and Survive. Harmondsworth: Penguin, pp. 223-226.

Escobar, A. (2001) 'Culture sits in places', Political Geography, 20(2): 139-74.

Featherstone, D.J. (2003) 'Spatialities of transnational resistance to neo-liberal globalisation: the maps of grievance of the inter-continental caravan', Transactions of the Institute of British Geographers, 28(4): 404-21.

Featherstone, D.J. (2004) 'Spatial relations and the materialities of political conflict: the construction of entangled political identities in the London and Newcastle Port Strikes of 1768', Geoforum, Special Issue on Material Geographies, 35(6): 701-11.

Featherstone, D.J. (2005) 'Towards the relational construction of militant particularisms: or why the geographies of past struggles matter for resistance to neo-liberal globalization', Antipode, 37(2): 250-71.
Flint, C. (2003) 'Political geography: context and agency in a multiscalar framework', Progress in Human Geography, 27(5): 637-48

Gibson-Graham, J.K. (2002) 'Beyond global vs. local: economic politics outside the binary frame', in A. Herod and M.W. Wright (eds), Geographies of Power: Placing Scale. Oxford: Blackwell, pp. 25-60.

Glassman, J. (2003) 'From Seattle (and Ubon) to Bangkok: scales of resistance to corporate globalization', Society and Space, 19(4): 513-33.

Gottmann, J. (1951) 'Geography and international relations', World Politics, 3(1): 153-73.

Graeber, D. (2002) 'The new anarchists', New Left Review, 13: 61-73.

Hardt, M. and Negri, A. (2000) Empire. Cambridge, MA: Harvard University Press.

Hardt, M. and Negri, A. (2004) Multitude: War and Democracy in the Age of Empire. New York: Penguin Press.

Harvey, D. (1982) The Limits to Capital. Oxford: Blackwell.

Harvey, D. (1985a) The Urbanization of Capital. Oxford: Blackwell.

Harvey, D. (1985b) Consciousness and the Urban Experience. Oxford: Blackwell.

Harvey, D. (1989a) 'From urban managerialism to urban entrepreneurialism', Geografiska Annaler B, 71(1): 3-17.

Harvey, D. (1989b) The Condition of Postmodernity. Oxford: Blackwell.

Harvey, D. (1993) 'From space to place and back again', in J. Bird et al. (eds), Mapping the Futures. London: Routledge, pp. 3-29.

Harvey, D. (1996) Justice, Nature and the Geography of Difference. Oxford: Blackwell.

Harvey, D. (1998) 'The Humboldt connection', Annals of the Association of American Geographers, 88(4): 723-30.

Harvey, D. (2000) Spaces of Hope. Edinburgh: Edinburgh University Press.

Harvey, D. and Hayter, T. (eds) (1993) The Factory and the City. London: Mansell.

Herod, A. (1995) 'The practice of international labor solidarity and the geography of the global economy', Economic Geography, 71(4): 341-63.

Herod, A. (1997) 'Labor as an agent of globalization and as a global agent', in K.R. Cox (ed.), Spaces of Globalization: Reasserting the Power of the Local. New York and London: Guilford Press, pp. 167-200.

Herod, A. (2006) 'Geographies of labour organizing in the new economy: examples from the United States', in P. W. Daniels, J. V. Beaverstock, M. J. Bradshaw and A. Leyshon (eds), Geographies of the New Economy. Routledge: London.

Herod, A. and Wright, M. (2002) 'Placing scale', in A. Herod and M. Wright (eds), Geographies of Power. Oxford: Blackwell, pp. 1-14.

Hinchliffe, S. (2000) 'Entangled humans specifying powers and their spatialities', in J.P. Sharp, C. Philo, R. Paddison and P. Routledge (eds), Entanglements of Power: Geographies of Domination/Resistance. London: Routledge, pp. 219-37. Howitt, R. (2003) 'Scale', in J.A. Agnew et al. (eds), A Companion to Political Geography. Oxford: Blackwell, pp. 138-57.

Johns, R. (1998) 'Bridging the gap between class and space: US worker solidarity with Guatemala', Economic Geography, 74(3): 252-71. 
Jonas, A.E.G. (1994) 'Editorial', Society and Space, 12(3): 257-64. Kaldor, M. (2003) Global Civil Society: An Answer to War. Cambridge: Polity Press.

Kirby, A. (2002) 'Popular culture, academic discourse, and the incongruities of scale', in A. Herod and M. Wright (eds), Geographies of Power. Oxford: Blackwell, pp. 171-91.

Klein, N. (2002) 'Farewell to "the end of history": organization and vision in anticorporate movements', in L. Panitch and C. Leys (eds), Socialist Register 2002: A World of Contradictions. London: Merlin Press, pp. 1-14.

Laclau, E. and Mouffe, C. (1985) Hegemony and Socialist Strategy. London: Verso.

Latour, B. (1993) We Have Never Been Modern, trans. C. Porter. Cambridge, MA: Harvard University Press.

Latour, B. (1996) 'On actor-network theory: a few clarifications', Soziale Welt, 47: 369-81.

Mamadouh, V., Kramsch, 0. and van der Velde, M. (2004) 'Articulating local and global scales', Tijdschrift voor Economische en Sociale Geografie, 95(5): 455-66.

Marston, S.A., Jones, J.P. III and Woodward, K. (2006) 'Human geography without scale', Transactions of the Institute of British Geographers, 30(4): 416-32.

Massey, D. (1993) 'Power-geometry and a progressive sense of place', in J. Bird et al. (eds), Mapping the Futures. London: Routledge, pp. 59-69.

Massey, D. (1999a) Power-Geometries and the Politics of Space-Time. Department of Geography, University of Heidelberg.

Massey, D. (1999b) 'Politics and space-time', in D. Massey et al. (eds), Human Geography Today. Cambridge: Polity Press, pp. 279-94.

Massey, D. (2004) 'Geographies of responsibility', Geografiska Annaler B, 86(1): 5-18.

Massey, D. (2005) For Space. London: Sage.

Medvedev, R. and Medvedev, Z. (1982) 'The USSR and the arms race', in E.P. Thompson et al., Exterminism and Cold War. London: Verso, pp. 153-74.

Merrifield, A. (1993) 'The struggle over place: redeveloping American Can in southeast Baltimore', Transactions of the Institute of British Geographers, 18(1): 102-21.

Merrifield, A. (2002) 'Seattle, Quebec, Genoa: après le déluge ... Henri Lefebvre?', Environment and Planning D: Society and Space, 20: 127-34.

Miller, B. (1994) 'Political empowerment, local-central state relations, and geographically shifting political opportunity structures', Political Geography, 13(5): 393-406.

Miller, B. (2004) 'Spaces of mobilization', in C. Barnett and M.M. Low (eds), Spaces of Democracy. London: Sage, pp. 223-46.

Murdoch, J. (1998) 'The spaces of actor-network theory', Geoforum, 29(4): 357-74.

Murdoch, J. and Marsden, T. (1995) 'The spatialization of politics', Transactions of the Institute of British Geographers, 20(3): 368-80.

Novelli, M. (2004) 'Globalizations, social movement unionism and new internationalisms: the role of strategic learning in the transformation of the Municipal Workers Union of EMCALI1', Globalization, Societies and Education, 2(2): $161-90$
Oslender, U. (2004) 'Fleshing out the geographies of social movements', Political Geography, 23(7): 957-85.

Oza, R. (2001) 'Showcasing India: gender, geography and globalization'. Signs: Journal of Women in Culture, 26(4): 1067-95.

Palmer, B.D. (1994) E.P. Thompson: Objections and Oppositions. London: Verso.

Perreault, T. (2003) 'Changing places: transnational networks, ethnic politics, and community development in the Ecuadorian Amazon', Political Geography, 22(1): 63-88.

Racek, V. (1982) 'Letter to E.P. Thompson', in E.P Thompson, Zero Option. London: Merlin Press, pp. 81-5.

Routledge, P. (1993) Terrains of Resistance: Nonviolent Social Movements and the Contestation of Place in India. Westport, CT: Praeger.

Routledge, P. (2003) 'Convergence space: process geographies of grassroots globalization networks', Transactions of the Institute of British Geographers, 28(3): 333-49.

Sadler, D. (2000) 'Organizing European labour: governance, production, trade unions and the question of scale', Transactions of the Institute of British Geographers, 25(2): 135-52.

Slater, D. (2002) 'Other domains of democratic theory: space, power, and the politics of democratization', Environment and Planning D: Society and Space, 20: 255-76.

Slater, D. (2003) 'Geopolitical themes and postmodern thought', in J.A. Agnew et al. (eds), A Companion to Political Geography. Oxford: Blackwell, pp. 75-92.

Smith, N. (1984) Uneven Development. Oxford: Blackwell.

Smith, N. (1989) 'Geography as museum', in N. Entrikin and S. Brunn (eds), Reflections on 'The Nature of Geography'. Washington, DC: AAG Publications, pp. 89-120.

Smith, N. (1992) 'Geography, difference and the politics of scale', in J. Doherty, E. Graham and M. Malek (eds), Postmodernism and the Social Sciences. London: Macmillan, pp. $57-79$.

Smith, N. (2000) 'Global Seattle', Environment and Planning D: Society and Space, 18: 1-3.

Smith, N. and Katz, C. (1993) 'Grounding metaphor', in M. Keith and S. Pile (eds), Place and the Politics of Identity. London: Routledge, pp. 67-83.

Staeheli, L.A. (1994) 'Empowering political struggle', Political Geography, 13(5): 387-91.

Taylor, P.J. (1981) 'Geographical scales within the worldeconomy approach', Review, 5(1): 3-11.

Taylor, P.J. (1982) 'A materialist framework for political geography', Transactions of the Institute of British Geographers, NS, 7(1): 15-34.

Thompson, E.P. (1980) Writing by Candlelight. London: Merlin Press.

Thompson, E.P. (1982) Zero Option. London: Merlin Press.

Townsend, J.G., Porter, G. and Mawdsley, E. (2004) 'Creating spaces of resistance: development NGOs and their clients in Ghana, India and Mexico', Antipode, 36(4): 871-89.

Wainwright, J., Prudham, S. and Glassman, J. (2000) 'The battles in Seattle: micro-geographies of resistance and the challenge of building alternative futures', Environment and Planning D: Society and Space, 18(1): 5-13. 
Watson, S. (2004) 'Cultures of democracy', in C. Barnett and M.M. Low (eds), Spaces of Democracy. London: Sage, pp. 207-22.

Wial, H. (1994) 'New bargaining structures for new forms of business organization', in S. Friedman, R.W. Hurd, R.A. Oswald and R.L. Seeber (eds), Restoring the Promise of American Labor Law. Ithaca, NY: ILR Press, pp. 303-13.
Wills, J. (2002a) 'Bargaining for the space to organize in the global economy: a review of the Accor-IUF trade union rights agreement', Review of International Political Economy, 9(4): 675-700.

Wills, J. (2002b) 'Political economy III: neo-liberal chickens, Seattle and geography', Progress in Human Geography, 26(1): 90-100. 